\title{
Relationship between Social Networking Sites and Observational Learning among Senior Secondary School Students in Mbaitoli Local Government Area, Imo State, Nigeria
}

\author{
Beatrice Adanna Achilike (PhD) \\ Chibueze Utum Mgboro(PhD) \\ Department of Educational Foundations, \\ Ebonyi State University, Abakaliki, Ebonyi State, Nigeria \\ Agbasiere, Emmanuel Patrick \\ Nnamdi Azikiwe University Awka,Anambra State, Nigeria
}

Doi: 10.19044/esj.2018.v14n7p324 URL:http://dx.doi.org/10.19044/esj.2018.v14n7p324

\begin{abstract}
Social Networking Sites are a type of virtual community which enables many people to interact and share ideas or interests. Social networking is rapidly changing the way the world is doing virtually everything, from the way people access information to the way people communicate and most importantly, the way they interact. This study investigated the relationship between Social Networking Sites and Observational Learning of Senior Secondary School students in Mbaitoli Local Government Area, Imo State, Nigeria. Four research questions with the corresponding hypotheses were generated. The objectives of the study centered on investigating the relationship between four social networking sites namely: Facebook, Instagram, Twitter and YouTube to observational learning. The correlational study design was adopted for the study. Simple random sampling was used to draw a sample of 560 students from the population of the study. The selfdesigned instrument was of two parts: A and B. Pearson Product Moment Correlation was used to answer the research questions while the hypotheses were subjected to critical probability level of 0.05 alpha levels. Findings to this study revealed that there is a significant positive relationship between social networking sites and observational learning; some of which include enhancement of informative endowment as in the case of Facebook, live-video functionality to stories in the case of Instagram and acquisition of vocational skills from YouTube. The paper at the end recommended that more encouragement should be given to students to enable them benefit adequately
\end{abstract}


and positively from the gains of social networking channels vis-a-vis observational learning.

Keywords: Facebook, Instagram, You Tube, Twitter and Observational Learning.

\section{Introduction}

Learning occurs not only through conditionality but also through observations from others. Observation learning in which we observe and imitate others, also plays a significant role. The process of observing and imitating specific behavior is often called modeling. With this Kemjika (2013), observed this type of learning to mean when people modify their behavior by observing the behavior of the other people around them. According to Chujor (2011), the plea of this concept holds that people often learn not only by having their own behavior reinforced but also by observing other people perform behaviours and receive reinforcement. These other people, he called models. Therefore, when people modify their behavior by observing other people's behavior, that is those around them, it is regarded as observational learning.

Some of the factors that contribute to this observational learning include individuals who are warm and nurturing in nature, those who receive rewards for their behavior, individuals who lack confidence of their abilities, a confusing situation amongst others.

Observational learning can take the form of positive or negative initiation depending on what interests or intrigues the observer has. This made Kemjika (2013) to note that certain behaviours are acceptable and encouraged in a given society,likewise certain behaviours are unacceptable in the same society. Such behaviours are discouraged or punished when exhibited. It is through social learning that some individuals especially youths or students learn which behavior their society accepts and expects from members as well as those abhorred from the members. Some students model after the way their teacher speaks, walks, dresses or how he/she demonstrates activities during teaching-learning process. Some of these students even at times observe their classmates, roommates, senior or even juniors and imitiate such learnt behaviours unknowingly. This is a demanding process the observer must have interest, particular attention and at the same time be motivated to follow almost all of the observed activities to get himself well acquainted.

Albert Bandura in his famous social learning theory demonstrated observational learning in his experiment on Bobo-doll in 1963 (Kemjika, 2013). In this research work, it was observed that aggressive behavior can be learned through observation and imitation as the Nursery school children who were exposed to aggressive model saw the adults hit a doll aggressively. They were shown later to have learned the aggressive behavior. 
In the above experiments, the children were not rewarded for learning to occur, but it did independently (Nwankwo, 2011). In real life situation, children who watch some horrors films and wrestling have been found to be aggressive and violent in their interactions with their fellow peers.

According to Less-Wrong(2014), skills like writing, speech craft and social skills are different from mere procedural skills as they are best acquired by observational learning. Although this type of learning are learnt from parents, teachers and members of peer groups, it can also be learnt from social networking site, including electronic and the print media. According to Cherry (2017), during the first half of the 20th-century, the behavioral school of psychology became a dominant force. The behaviorists proposed that all learning was as a result of direct experience with the environment through the processes of association and reinforcement. While Bandura's theory is also rooted in many of the basic concepts of traditional learning theory, he believed that direct reinforcement could not account for all types of learning.

For example, children and adults often exhibit learning for things with which they have no direct experience.

On the other hand, the behavioral theories of learning upholds that all learning was the result of associations formed by conditioning, reinforcement, and punishment, Bandura's social learning theory proposed that learning can also occur simply by observing the actions of others.

For this paper, the focus is on Social Networking Site. The social networking site according to Webopedia.com is defined as the phrase used to describe any web site that enable users to create public profiles within that web site and form relationships with other users of the same web site who access their profile. In the same vein, Boyd and Ellison (2007) described this type of site as one web-based service that allow semi-public profile within a bounded system, to articulate a list of other users with whom they share a connection, and view and traverse their list of connections and those made by others within the system. Agusto and Abbas (2010) look at social networking site as communication tools where youths reason together and keep in touch with one another. The different platforms of social networking sites or channels include Facebook, Twitter, YouTube, Instagram, 2go, Google messenger, Whatsapp messenger, etc.

Facebook messenger is a social networking platform where an individual registers and become able to access and upload videos, pictures, write articles, send and receive messages. It is universal and for all type of internet accessible phone. It is for all ages and easy to operate. It is free, promotes and facilitates interaction between friends, family and colleagues. With this Eler (2012) opined that facebook is an accepted means of communication which users use to write short update on their lives. 
Twitter is an online social networking service and micro blogging service that enables its users to send and read text-based messages of up to 140 characters, known as 'tweets'. Its platform is widely used as it has become one of the ten most visited websites on the internet that is "the SMS of the internet". (http://en.m.wikipedia.orgi/wiki/twitter). McArthur and Bostedo - Conway (2012) in a quantitative study reported significant positive correlations between students' Twitter use and learning. They have recommended the use of Twitter for teacher- student interactions and lifelong learning experiences.

Although not all phones can access the twitter due to its high technicality, Radio stations, Television Stations, Newspaper vendors and large companies benefit from the platform. Its messages can be received as a text message if the user opted for it.

Through twitter, prominent events like world cup, elections of countries musical concerts or even marriage or death of celebrities are made known quicker than any other means of communication.

YouTube is a kind of social media platform where personal videos are downloaded and shared. This media provides for unedited stories. Although it is complex to operate but it has a wider coverage. Individuals can acquire skills like make-up, bead-making, hat-making, cooking, shoe-making, interior decorations, Tie-dye and other vocational activities. The steps or procedures are shown also.

Instagram is a kind of platform that is basically used for posting pictures and videos. Although it is of a brief coverage, individuals use it as means of advertising their products through on-line shops. It brings people together in a page especially students groups. It also gives news update; people can also watch observe new trends of fashion, technology, etc.

Social media networks are designed for the purpose of communal connections. Today's students are accessing Facebook, Twitter and even Instagram to connect and share with those around them (Baker, 2013). One of the most interesting things about social media is that users can interact and engage with each other solely through a Web presence, perhaps never even meeting in person. Also, by the use Social networking sites, students are able to share among themselves day in and day out, giving and receiving information at rapid speeds. This information is more than funny cat videos; they share views and opinions; tips, tricks, and even DIY projects; and, among students, helpful information for classes. Their ability to assess, analyze, retain and share information is growing rapidly and they often don't even realize they're developing these skills. Senoir secondary students makes use of social networking sites unconsciously linking their beneficial outcome vis -a- vis observational learning This survey is aimed at establishing a link between observational learning and social networking sites among senior secondary 
school students within the age brackets of 14 -18 years in Mbaitoli Local Government Area of Imo state south eastern Nigeria.

\section{Statement of Problem}

Good academic performance is important to every institution of learning. In other to achieve this, various teaching techniques have been employed to achieve this. However, today there seem to be a derivation, distraction and divided attention between social networking sites or channels and its activities on learning among the students at the Senior Secondary School level. It is observed that students devote more attention to social media instead of keenly observing and try to make an input on what they were taught.

In addition, the proximity to this social networking platform is very close that a student can be chatting with more than one social network platform at the same time. In trying to catch up with these networking activities, a student can be glued to his/her mobile phone for hours thereby constraining every other activity until he/she is satisfied with the process.

This attachment to these social networking sties has given so much concern to parents, teachers and the society as many internet safety managers are on the lookout for how to control or even eliminate the teenagers from social networking sites and other online spaces. This is to control havoc befalling the lives of these youths, despite the fact that these sites however have their own educational and psychosocial benefits which could be directed for the benefits of these students.

Nigeria is a developing country with myriads of teething problems on her educational sector. Not all the secondary school students are aware of the educational benefits of social networking sites. This makes the affirmative effects of social networking in education not to be glaringly perceptive.

Therefore, the researchers tried to investigate whether social networking site has any relationship to observational learning among Senior Secondary School students in Mbaitoli Local Government Area, Imo State, Nigeria.

\section{Aim and Objectives of the Study}

The purpose of the study is to find out whether social networking has any relationship with observational learning among Senior Secondary School students in Mbaitoli Local Government Area, Imo State, Nigeria.

Specifically, the study tried to:

1. Find out the relationship between the use of Facebook and Observational Learning in Senior Secondary Schools in Mbaitoli Local Government Area, Imo State, Nigeria. 
2. Establish the relationship between the use of Instagram and Observational Learning among Senior Secondary Schools in Mbaitoli Local Government Area, Imo State, Nigeria.

3. Ascertain the relationship between the use of YouTube and Observational Learning among Senior Secondary Schools students in Mbaitoli Local Government Area, Imo State, Nigeria.

4. Find out the relationship between the use of Twitter and Observational Learning among Senior Secondary School students in Mbaitoli Local Government Area, Imo State, Nigeria.

\section{Research Questions}

The following research questions guided the study

1. What is the relationship between the use of Instagram and Observational Learning among Senior Secondary Schools students in Mbaitoli Local Government Area, Imo State, Nigeria?

2. What is the relationship between the use of YouTube and Observational Learning among Senior Secondary School in students Mbaitoli Local Government Area, Imo State, Nigeria?

3. What is the relationship between the use of Twitter and observational learning among Senior Secondary School students in Mbaitoli Local Government Area, Imo State, Nigeria?

4. What is the relationship between the use of Facebook and Observational Learning among Senior Secondary schools students in Mbaitoli Local Government Area, Imo State, Nigeria?

\section{Hypotheses} levels.

The following null hypotheses were tested at 0.05 significant alpha

1. There is no significant relationship between the use of Facebook and Observational Learning among Senior Secondary school students in Mbaitoli Local Government Area, Imo State, Nigeria.

2. There is no significant relationship between the use of Instagram and Observational Learning among Senior Secondary School students in Mbaitoli Local Government Area, Imo State, Nigeria.

3. There is no significant relationship between the use of YouTube and Observational Learning among Senior Secondary school students in Mbaitoli Local Government Area, Imo State, Nigeria.

4. There is no significant relationship between the use of Twitter and Observational Learning among Senior Secondary school students in Mbaitoli Local Government Area, Imo State, Nigeria. 


\section{Methodology}

This study used the correlational research design. The population of the study comprised all the 6,185 Senior Secondary School students in SS II in the 14 public Senior Secondary Schools in Mbaitoli Local Government Area, Imo State, Nigeria.

The sample size was 600 students. A simple random sampling techniques was used. Four self designed instruments of Facebook Use Scale (FUS), Instagram Use Scale (IUS), YouTube Use Scale (YUS), Twitter Use Scale (TUS) and Observational Learning Scale (OLS) were used for data collection.

The instrument used has two sections, A and B, Section A consists of the Demographic factors while section B embraces Non-cognitive and Nonstandardized 50 items. The self-designed instruments were structured after modified Likert four-points relating to rating scales of Strongly Agree (4points), Agree (3-points), Disagree (2-points), and Strongly Disagree (1point). Face and content validities were rightly ensured. The Internal Consistency Reliability was used to answer the research questions while the hypotheses were subjected to critical probability level of 0.05 alpha levels.

\section{Results}

The results of the findings of the study are presented interpreted and discussed as follows.

\section{Research Question One}

What is the relationship between the use of Facebook and Observational learningamong Senior Secondary school students in Mbaitoli Local Government Area, Imo State, Nigeria.

\section{Hypothesis One}

There is no significant relationship between the use of facebook and Observational

Learning among Senior Secondary School students in Mbaitoli Local Government Area, Imo State, Nigeria.

Table 1: Pearson Product Moment Correlation Statistic of the relationship between Facebook use and observational learning

\begin{tabular}{|l|l|l|l|l|}
\hline Category & $\mathbf{N}$ & $\mathbf{R}$ & Sig & Remark \\
\cline { 1 - 3 } & \multirow{2}{*}{6,185} & \multirow{2}{*}{0.97} & 0.03 & $\begin{array}{l}\text { Statistically } \\
\text { significant }\end{array}$ \\
\cline { 1 - 3 } & & & & \\
\hline
\end{tabular}

Table 1 above showed that the Pearson Product Moment coefficient $r$ is given as 0.97. This indicates that there is a high positive relationship between Facebook use and observational learning among Senior Secondary 
School II students in Mbaitoli Local Government Area, Imo State, Nigeria.The calculated probability value of 0.03 is less than the critical probability p-value of 0.05 , therefore, the null hypothesis is rejected. This implies that there is significant relationship between the use of facebook and observational learning in Senior Secondary Schools in Mbaitoli Local Government Area, Imo State, Nigeria.

\section{Research Question Two}

What is the relationship between the use of Instagram and Observational Learning among Senior Secondary School students in Mbaitoli Local Government Area, Imo State, Nigeria?

\section{Hypothesis 2}

There is no significant relationship between the use of instagram and observational learning among Senior Secondary School students in Mbaitoli Local Government Area, Imo State, Nigeria.

Table 2: Pearson Product Moment correlation statistics of the relationship between Instagram and Observational learning

\begin{tabular}{|l|l|l|l|l|}
\hline Category & N & R & Sig & Remark \\
\hline Instagram & 6185 & 0.79 & 0.04 & $\begin{array}{l}\text { Statistically } \\
\text { significant }\end{array}$ \\
\hline Observational learning & & & \\
\hline
\end{tabular}

Table 2 revealed the Pearson Product Moment coefficient $\mathrm{r}$ as 0.79. This shows that there is a high positive relationship between Instagram use and observational learning among Senior Secondary School Students in Mbaitoli Local Government Area, Imo State, Nigeria. The calculated probability value of 0.04 is less than the critical probability p-value of 0.05 , therefore, the null hypothesis is rejected. By implication there is a significant relationship between instagram use and observational learning among Senior Secondary School Students in Mbaitoli Local Government Area, Imo State, Nigeria.

\section{Research Question Three}

What is the relationship between the use of YouTube and Observational Learning among Senior Secondary School students in Mbaitoli Local Government Area, Imo State, Nigeria.

\section{Hypothesis Three}

There is no significant relationship between the use of YouTube and observational learning in Mbaitoli Local Government Area, Imo State, Nigeria. 
Table 3: Pearson Product Moment Correlation Statistics of the relationship between YouTube and observation learning

\begin{tabular}{|l|l|l|l|l|}
\hline & N & R & Sig & Remark \\
\hline YouTube & 6185 & 0.65 & 0.00 & $\begin{array}{l}\text { Statistically } \\
\text { significant }\end{array}$ \\
\cline { 1 - 1 } $\begin{array}{l}\text { Observational } \\
\text { learning }\end{array}$ & & & & \\
\hline
\end{tabular}

Table 3 above revealed that the Pearson Product Moment coefficient is given as 0.65 . This indicates a high positive relationship between YouTube and Observational Learning among Senior Secondary School students in Mbaitoli Local Government Area, Imo State, Nigeria.This implies that there is a significant relationship between the use of YouTube and Observational Learning among Senior Secondary Schools Students in Mbaitoli Local Government Area, Imo State, Nigeria.

\section{Research Question Four}

What is the relationship between the use of Twitter and Observational Learning among Senior Secondary School Students in Mbaitoli Local Government Area, Imo State, Nigeria.

\section{Hypothesis Four}

There is no significant relationship between the use of Twitter and Observational Learning among Senior Secondary School Students in Mbaitoli Local Government Area, Imo State, Nigeria.

Table 4: Pearson Product Moment Correlation Statistics on the relationship between Twitter and Observational learning

\begin{tabular}{|l|l|l|l|l|}
\hline Category & N & R & Sig & Remark \\
\hline Twitter & \multirow{2}{*}{6185} & 0.73 & 0.01 & $\begin{array}{l}\text { Statistically } \\
\text { significant }\end{array}$ \\
\cline { 1 - 3 } $\begin{array}{l}\text { Observational } \\
\text { learning }\end{array}$ & & & & \\
\hline
\end{tabular}

Table A has shown that Pearson Product Moment coefficient $r$ is given as 0.73 . By implication, there is a high positive relationship between Twitter and observational learning among Senior Secondary Schools Students in Mbaitoli Local Government Area, Imo State, Nigeria. The calculated probability value of 0.01 is less than the critical probability p-value of 0.05 . Therefore, the null hypothesis is rejected. This indicates a significant relationship between the use of Twitter and observational learning among Senior Secondary School Students in Mbaitoli Local Government Area, Imo State, Nigeria.

\section{Discussion of Findings}

The findings of this study are as presented under the subheading that follow below. Relationship between Facebook use and Observation 


\section{Learning}

The findings of the study has shown that Facebook and observational learning among Senior Secondary School students in Mbaitoli Local Government Area, Imo State, Nigeria are both good means of observational learning because its developed network enhances advanced functionalities via applications. It also connects a login authentication service that creates and aids across platform and customizable web application. Students in the study area use this platform to post photos and videos that have informative endowment. They are get information which helps them grow in intellect and also enhances creativity in them. In support of this, Clark and Roberts (2010), Dewyer, Hiltz and Passerni (2007), are all of the opinion that social networking sites or channels like facebook is a positive change to the development of its members. Despite all criticisms, may be as a result of wrong usage, facebook is an accepted means of communication (Eler, 2012).

\section{Relationship between Instagram use and Observation Learning}

The findings of this study has revealed that there is a significant positive high relationship between Instagram use and Observational Learning. This platform is basically used for positing pictures and videos. It bring people together in pages especially students group. It gives news update as people can also observe. Here people observe new trends of fashion, technologically. Users also have the option of making their profile private so that only their followers can view their posts. Instagram adds live-video functionality to stories. These has made Instragram's popularity to be described as that which has sparked an engaging community including dedicated trends' (Instagram Wkipedia https://en.wikipedia.org>wi ki>Instagram). Findings also shows that most students in Mbatoilo Local Government Area use instagram in following celebrities and their life styles which increases observational learning as some tend to copy or mimic these life styles.

\section{Relationship between YouTube use and Observational Learning}

The findings revealed that there is a significant positive high relationship between YouTube use and observational learning among Senior Secondary School students in Mbaitoli Local Government Area, Imo State, Nigeria. Although YouTube is complex especially for some young individuals, it has a wide coverage. Students in the study area operate this platform to acquire skills like make-up, bead making, hat making, cooking, making shoes, tye and dye and other vocational activities. The slogan for YouTube website is "Broadcast yourself". This supports this finding as teaching and learning can be published in videos individuals would have created. This is called instructional videos .Some of the students also uses this platform in upgrading 
their interest and skills in sports as some reported watching football highlights and other type of sports on YouTube.

\section{Relationship between Twitter and observational learning}

It was shown that there is a significant positive high relationship, between Twitter and observational learning among the Senior Secondary Students in Mbaitoli Local Government Area, Imo State, Nigeria.

Twitter as a social network website allows users to publish short messages that are visible to other users. It could be in form of communication between friends and family, a way to publicize events or as a customer relations tool. All these can be extended to the teaching and learning process as McArthur and Bostedo-Conway (2012) earlier noted that this media has significant positive correlations between students' Twitter use and learning. Krishna (2015) noted also that it is a pedagogical tool and so needed in the teaching learning process. Most of the students sampled in the study area reported that they seldom use twitter handle however, those using the platform reported using it in following world class celebrities and mimicking some of their life styles.

\section{Conclusion}

Social networking sites have positively affected the modern society a great deal and have changed some people's habit. Correct use of features and opportunities of social networking sites supports students' educational process with active and lifelong learning, creativity, problem solving, cooperation and multifaceted interaction and critical thinking. Furthermore, it develops communication skills, aid participation commitment, strengthen peer support and enables realization of cooperation based learning. In addition, social networking sites can be easily used and incorporated in to educational practices successfully.

From the findings of the results of this study, it is concluded that social networking sites/channels (Facebook, Instagram, YouTube and Twitter have a high positive relationship with observational learning. This clearly shows that an increase recorded in the independent variables eventually leads to increase in the dependent variables indicating a positive correlation between observational learning and social networking sites .

\section{Recommendations}

From the findings of the study, this work recommends that:

- Students should be encouraged to make adequate use of Facebook to model worthwhile behaviours and activities posted on the platform instead of using it for frivolities'. 
- There is need for conferences and workshops to be organized by internet specialists on the competent use of some social networking sites by teachers and students. This will enhance attainment of learning objectives.

- Students should be exposed and taught how to use various social media channels especially YouTube from young age to enhance easier access and adequate benefit through observational learning and social networking.

- Twitter sites/channels should be adopted by teachers to enhance the teaching-learning process.

\section{References:}

1. Agusto, D.E. \& Abbas, J. (2010). Higher School Seniors' Social Network and other ICT use preferences and concerns. Proceedings of the American Society for Information Science and Technology. 47(1), $1-10$.

2. Baker,J. (2013). How Students benefit from using Social Media. Retrieved $6^{\text {th }}$ December, 2017 from www.edudemic.com?howstudent-benefitfrom-using-social-media.

3. Boyd, D. \& Elisson, N.O. (2007). Social Network Sites: definition, history and scholarship. Journal of Computer-Mediated Communication. 13(1) 210-230.

4. Cherry,K., (2017).What is social learning theory? Retrieved $8^{\text {th }}$ December,2017 at www.verywell.com/social-learning -theory.

5. Chujor,A., (2011): Recurrent problems among secondary school students. Retrieved December 5,2017 at http://files.eric.ed.gov/fulltext/EJ1135738.pdf.

6. Clark,L.A., \& Roberts,S.J., (2010). Employers' Use of Social Networking Sites. A socially Irresponsible Practice Journal of Business Ethics 95(4): 507.

7. Dewyer,C., Hiltz ,S.R.,and Passerini,K., (2007). Trust and Privacy Concern within Social Networking Site: Comparison of Facebook and Myspace. AMCIS 2007 Proceedings Paper 339 NY.

8. Eler, A. (2012). Why do people use Facebkk? http://readwrite.co,/2012/10/16/studyWhydopeopleusefacebook.http:/ /en.rn.wikipedia.org/wki/twitter.Instagram -Wikipedia https://en.wikipedia.org>wiki>lnstragram

9. Kemjika, O.G (2013). Educational Psychology. Onitsha: Fabson Printing \&Publishing Co.Ltd.

10. Krishna, B. (2015). Is Twitter an effective pedagogical tool in higher education? Perspectives of Education? Perspectives of Education Graduate Students. 
11. Less-Wrong, (2014). Observational Learning and the Importance of High quality examples.http://lesswrong.com/lw/kog/observational. learning and the importance of high.

12. McArthur, J.A \& Bostedo-Conway, K. (2012). Exploring the relationship between Student in structure interaction on Twitter and Student Perception of teachers behavior.

13. Nwankwo,E., (2001). Psychology of Learning: The Human Perspective. Port Harcourt: Pam Unique Publishers.

14. YouTube Definition - Tech Terms https://technterms. com>defmition >youtube updated: October 7, 2009. 